out with a needle, a great deal of bleeding takes place, and the concretion is obscured from view. The electrolysis needle is extremely useful in giving a bloodless field of operation; the point of the needle is inserted under the concretion, and, in most cases, the concretion is easily dislodged. Granulomata of the conjunctiva following squint operations or excision of the eyeball can be easily cauterised at the base with the electrolysis needle and then snipped off ; again the operation is practically bloodless. The electrolysis needle acts as a cautery, and prevents recurrence of granulation tissue.

Naevi of the skin of the lids are destroyed by inserting the electrolysis needle into one or two venules: coagulation follows rapidly.

If the electrolysis needle is used judiciously in the treatment of all these conditions (i.e., weak current and short applications), no scarring of tissue should follow.

The method described above is used frequently by dermatologists, and this paper is an attempt to indicate its wider application in ophthalmology.

\title{
$\underline{\underline{ }}$ \\ THE DIFFERENTIAL DIAGNOSIS OF ORBITAL GUMMA
}

BY

\author{
Dr. Else Wolfsohn-Jaffé \\ ASSISTANT TO PROFESSOR DR. GUTMANN, BERLIN
}

THE differential diagnosis of retrobulbar tumours of the orbit is often very difficult. Frequently only an exophthalmos and secondary changes in the eyeball suggest the presence, deep in the orbit, of a pathological process which cannot be detected by inspection, or by palpation, or by X-rays. In such cases any auxiliary means of diagnosis which may help to clarify the question as to whether there is a benign or a malignant tumour, or a chronic inflammatory process, may certainly be welcomed. The piezometer, an apparatus, by which the displaceability of the eyeball into the orbit can be measured, is such an auxiliary aid to diagnosis. Meller repeatedly drew attention to this clinical method in the "Zeitschrift für Augenheilkunde," in 1933, and reported that Gutmann's piezometer had been used to great advantage for many years in all cases of retrobulbar tumours in the Vienna Clinic. I refer the reader to Gutmann's works (e.g., Transactions of the Ophthalmological Society of the United Kingdom, 1934) for a detailed 
description of the piezometer and confine myself here to those of its features which are necessary for the comprehension of my paper. The apparatus is built along the same lines as a tonometer and, like the latter, is placed on the cornea, after the application of holocaine or pantocaine, with the patient lying down. A weight of $25 \mathrm{grm}$. is placed on the footplate of the piezometer and an indicator which is attached to the plate, marks off on a scale in tenths of a millimetre how far the weight displaces the eyeball into the orbit. Gutmann and Freyler have obtained values for the piezometric displaceability of the globe into the orbit in a large number of cases of fibroma, sarcoma, carcinoma and angioma of the orbit. The results were typical for each different tumour. Thus far, however, sufficient well-founded piezometer values for the rather rare gummatous affections of the orbit are still lacking. Only one single case of orbital gumma has been measured by Freyler with the piezometer up till the present. Dependable values, of course, must be based on a larger number of cases. For this reason I made several measurements with the piezometer in the course of one case of a gummatous affection of the orbit and should like to report the values obtained as well as the case history.

A woman patient, aged 64 years, came to the clinic for the first time in December, 1934. After a period of months she admitted that she had acquired lues 34 years previously; at that time she suffered from a syphilitic exanthema, and had an early abortion and a still-birth in the seventh month; no living children. Only one course of antisyphilitic treatment was carried out. Until the appearance of the eye affection, i.e., for a period of 34 years, she remained free from syphilitic afflictions.

Besides diplopia with vertical displacement the first examination did not disclose anything special. The visual acuity on both sides with $+1.0 \mathrm{D}$ cyl., vertical was $5 / 15$. Pupils on both sides slightly oval, but with normal reactions. Fundi normal. Wassermann reaction in blood: negative.

In August, 1935, there appeared a slight venous congestion in the left eye for the first time. This increased rapidly and in 4 weeks became intense. Simultaneously an exophthalmos set in on the left side and severe headache followed. An X-ray examination revealed normal findings as regards the bone but a slight shadowing of the left orbit, suggesting a coherent process. Nasal examination disclosed only a resection of the medial turbinated bone which had been performed in 1910; the sinuses were open. The neurological findings were normal. Apart from slight arteriosclerosis, nothing pathological was found generally; no symptoms of leukaemia or pseudo-leukaemia. The findings suggested a malignant tumour but in view of the history a course of treatments 
by inunction was begun early in September. Approximately three weeks later, a slight improvement in the ophthalmic signs set in. At the end of five weeks, however, the patient was in a very bad general condition, suffering from weakness, dizziness and pains in the extremities; this form of treatment was given up and a series of treatments with spirobismol was started in the middle of October. The patient was given 5 intra-muscular injections of spirobismol. Under this treatment her general condition improved but the bulbar protrusion and the venous congestion remained un. influenced, while the headache and facial pains became very severe. A definite sensitivity to pressure set in on the upper rim of the orbit. An orbital tumour was never palpable although a slight swelling could be felt for a short time on the upper rim of the orbit. On October 30,1935, the vision on the left side had been reduced to $5 / 50$; on the same day the first measurements of the piezometer displaceability and of the extra-orbital protrusion were taken. The extra-orbital protrusion amounted to : right 15 $\mathrm{mm}$., left $20 \mathrm{~mm}$; the piezometer values : right 14 , left 11 , i.e.. the globe on the healthy side could be displaced $1.4 \mathrm{~mm}$. , that on the affected side $1.1 \mathrm{~mm}$., into the orbit. Normally the piezometer values for both eyes are the same. Therefore, there must have been a hard resistance to further displacement deep in the left orbit On the basis of such a diminished piezometer value, an angiom for instance, whereby the displaceability is increased, can be elime inated from the diagnosis with certainty. In our case the differential diagnosis between tumour and gumma could only be decided ex juvantibus. The antisyphilitic treatment was continued in the form of a series of mercury injections beginning on November 30 , 1935. The patient was given two intragluteal injections of 0.5 c.c. of 10 per cent hydr.salicyl. each week-altogether ten injections. Ten days later the extra-orbital protrusion on the left side had sunk $2 \mathrm{~mm}$. to $18 \mathrm{~mm}$. and the piezometer value of the affected eye was 9.5 , i.e., the displaceability of the affected eye had been further reduced. Two weeks later the left extra-orbital protrusion was reduced by $1 \mathrm{~mm}$. to $17 \mathrm{~mm}$. and the vision returned to the normal of 5/15. The pain and congestion diminished. In March, 1936, one month after the completion of the series of mercury injections, the exophthalmos on the left side amounted only to $1 \mathrm{~mm}$., the congestion was limited to two episcleral veins and the vision was $5 / 15$, as before the beginning of the affection. However, the piezometer value, which was checked several times, remained at 9.5 ; therefore an increasing induration in the tissue behind the globe must have taken place.

There can be practically no doubt concerning the diagnosis of syphilis in our case. The decision ex juvantibus alone is not 
absolutely certain as there are so-called pseudo-tumours of the orbit arising in unspecific, chronically inflamed tissue which may respond to treatment with mercury. This group of pseudotumours, classified by Birch-Hirschfeld, has, however, been narrowed down by improved methods of diagnosis in favour of tuberculous and syphilitic new-growths. In view of the history the diagnosis of gumma in our case may be regarded as certain. The negative Wassermann reaction need not be regarded as contradictory for, according to Schönfeld's statistics in the handbook of dermatology by Arzt-Zieler, the Wassermann reaction is negative in as many as 30 per cent. of all cases of late syphilis and even in 40 per cent. of the cases of circumscribed late syphilis of the bones and joints. Furthermore sensitivity to pressure on the upper orbital margin (which was most definite in our case), pains in the region of the trigeminal nerve, and temporary disturbance of vision, which Birch-Hirschfeld attributes to a perineuritis of the optic nerve, are all symptoms of orbital syphilis.

Gummatous affections of the orbit are extremely rare. They amount to from 1 per cent. to 2 per cent. of all cases of syphilis of the eye and 0.013 per cent. of all diseases of the eye. An exhaustive list of all cases of orbital gumma up till 1907 has been compiled by Birch-Hirschfeld in the Graefe-Sämisch handbook. More recent literature may be found in Igersheimer's "Syphilis und" Auge," in the chapter " Orbita " by Birch-Hirschfeld in Schick Brückner's handbook of ophthalmology, and in the "Zentralblatt für Ophthalmologie." Gummata can arise primarily in the orbit or they can spread into it from a sinus or a cranial bone. The predilectory localizations are the upper orbital margin and the roof of the orbit. In the majority of cases orbital gummata arise in the periosteum-periostitis orbitae gummosa-and affect the bones and contents of the orbit secondarily. Theoretically it is possible for gummata to arise in the interior of the orbit and spread out along the lymphatic apparatus or the muscles of the eve. Such cases, however, are extremely rare and uncertain. Up till the present oniy a very few cases have been examined anatomically. The Graefe-Sämisch handbook describes the findings in 5 autopsies performed on persons who died of orbital gumma with subsequent gummatous meningitis. The findings of 5 other histological examinations in the case of patients who were operated on as a result of the incorrect diagnosis of tumour are published in more recent literature (cases Werner, Raffin, Laricchia, Musical, Hirata). Periostitis gummosa orbitae usually follows a course analagous to that of periostitis luetica of the cranial bones. The gummatous process arising in the periosteum can spread into the bones and lead to softening and decay of the thin orbital wall. In cases which ended fatally this type of softening with subsequent 
perforation into the interior of the cranium had taken place. Orbital gumma occurs in cases of both congenital and acquired syphilis. The earliest occurrence of this affliction observed was 8 weeks after the infection, the latest 30 years after the infection; in our case, as mentioned above, 34 years had elapsed since the infection.

The X-ray examination indicated that our patient was not affected by any pathological changes in the bones. The gum. matous process must therefore have been present in the periorbita - which does not reveal any contrast effects by X-rays-as well as in the tissue in the interior of the orbit. At the time when the affection had reached its severest point, when the exophthalmos amounted to $5 \mathrm{~mm}$., the registered piezometric displaceability of the afflicted eye was $0.25 \mathrm{~mm}$. less than that of the healthy one. At the conclusion of the treatment when all other symptoms of the disease had disappeared and the exophthalmos amounted to only $1 \mathrm{~mm}$., the piezometric displaceability of the afflicted eye was $0 \cdot 4$ $\mathrm{mm}$. less than that of the healthy one. This clearly suggests that an induration and cicatrization had taken place in the retrobulbar connective tissue of the orbit and that the change was of the nature of a specific healing process since it accompanied an amelioration of the whole affection in response to antisyphilitice treatment. In the case of orbital gumma reported by Freyler theree was an even greater reduction of the piezometric displaceabilitys of the eyeball into the orbit, namely $0.6 \mathrm{~mm}$. Meller found that return of the bulbar displaceability to the normal before the recession of the exophthalmos (caused by oedema in the tissues) was indicative of the efficacy of the irradiation of malignant tumours; in an analogous manner we inferred the success of the antisyphilitic therapy in our case from (inter alia) a gradual reduction of the piezometric displaceability. Thus the piezometer is an accessory aid in judging the success of an antisyphilitic cure in such a case. The reaction of a luetic affection to a series of antisyphilitic treatments is not necessarily always prompt, a fact which may make it very difficult to decide between continuing the cure or operating; the piezometer may then afford valuable guidance. According to the experience gathered in our case, a diminishing piezometer value signifies a healing tendency; furthermore, it is possible that the efficacy of a course of treatments-and therewith the syphilitic nature of an affection-may be revealed by this earlier than by other retrograde symptoms. Naturally it is not possible to generalize from one case; therefore the publication of further piezometric examinations in cases of orbital gumma is desirable. 


\section{Summary}

Gutmann's piezometer, an apparatus for measuring the displaceability of the eyeball into the orbit, may be used with success in the diagnosing of retrobulbar tumours. I examined one case of orbital gumma with the piezometer during the course of the affection and found that the displaceability of the globe into the orbit diminished during the healing of an orbital gumma and remained later permanently less than normal. Diminishing piezometer values during the course of an antisyphilitic cure indicate resorption and cicatrization of the pathological retrobulbar process, as expressed in the form of a fibrous induration, and contribute to the diagnosis of syphilis.

\section{LITERATURE}

Birch-Hirschfeld.-Die Krankheiten der Orbita. Handb. d. Augenheilk., v. Graefe-Saemisch, 2 Aufl., 1909.

Die Krankheiten der Orbita. Handb. d. Ophthal., by Schieck Brückner, Bd. III, 1930.

Gutmann, A.-Trans. Ophthal. Soc. U.K., Vol. LIV, 1934.

Freyler, H.-Erfahrungen mit dem Piezometer von Gutmann. Zeitschr. f. Augenheilk., Bd. LXXXII, p. 127, 1933.

Gutmann, A.-Piezometer zur Diagnostick retrobulbärer Orbitalgeschwülste. Zeitschr. f. Augenheilk., Bd. LXIII, p. 136, 1927.

Hirata, Z.-Ein Fall von Orbitalgumma, welcher bei der Untersuchung eine besondere Schwierigkeit bot. Jap. Ref.Zentralbl.f.d.ges. Ophthal., Bd. $\mathrm{XXV}$, p. 155:

Igersheimer.-Syphilis und Auge. 2 Aufl., p. 444, 1928.

Larrichia, E.-Entwicklung eines Kleingummas innarhalb der Augenhöhle. Ann. di Ottal., Vol. LVII, p. 198; Ref. Zentralbl. f. d. ges. Ophthal., Bd. XXII, p. 195, 1929.

Meller.-Zeitschr. f. Augenheilk, Bd. LXXX, p. 112, 1933.

Raffin, A.-Ueber orbitale Syphilis. Klin. Monatsbl.f. Augenheilk., Bd. LXVI, p. $147,1921$.

Werner.- Ueber syphilitische Gummabildung der Orbita. Inaug. Diss., Jena, 1913.

\section{SOME REMARKS ON OEDEMA}

BY

\section{J. A. van Heuven}

UTRECHT

Along various roads attempts have been made to approach the origin and nature of inflammations. These investigations were often made in what might be called a "static" way, i.e., an existing inflammation was thoroughly studied. That this manner of investigation was used so frequently may be due to the fact that in the days in which these problems were acute, not many other ways were available. Thus minute descriptions have been 